\title{
The Diverse Assemblage of Fungal Endophytes from Orchids in Madagascar Linked to Abiotic Factors and Seasonality
}

\author{
Kazutomo Yokoya ${ }^{1}$, Lawrence W. Zettler ${ }^{2}{ }^{\oplus}$, Jake Bell ${ }^{1}$, Jonathan P. Kendon ${ }^{1}$, Alison S. Jacob ${ }^{1}$, Emily Schofield ${ }^{1}$, \\ Landy Rajaovelona ${ }^{1}$ and Viswambharan Sarasan ${ }^{1, *}$ (]) \\ 1 Royal Botanic Gardens Kew, Richmond, London TW9 3AE, UK; kazyokoya@gmail.com (K.Y.); \\ jakebel193@gmail.com (J.B.); j.kendon@kew.org (J.P.K.); ali.jacob@virginmedia.com (A.S.J.); \\ emily_schofield2@outlook.com (E.S.); L.Rajaovelona@kew.org (L.R.) \\ 2 Department of Biology, Illinois College, Jacksonville, IL 62650-2299, USA; 1wzettle@ic.edu \\ * Correspondence: v.sarasan@kew.org
}

Citation: Yokoya, K.; Zettler, L.W.; Bell, J.; Kendon, J.P.; Jacob, A.S.;

Schofield, E.; Rajaovelona, L.; Sarasan, V. The Diverse Assemblage of Fungal Endophytes from Orchids in Madagascar Linked to Abiotic Factors and Seasonality. Diversity 2021, 13, 96. https://doi.org/10.3390/d13020096

Academic Editor: Michael Wink

Received: 3 January 2021

Accepted: 6 February 2021

Published: 23 February 2021

Publisher's Note: MDPI stays neutral with regard to jurisdictional claims in published maps and institutional affiliations.

Copyright: (c) 2021 by the authors. Licensee MDPI, Basel, Switzerland. This article is an open access article distributed under the terms and conditions of the Creative Commons Attribution (CC BY) license (https:// creativecommons.org/licenses/by/ $4.0 /)$.

\begin{abstract}
The inselbergs of the Central Highlands of Madagascar are one of many 'micro-hotspots' of biodiversity on the island, particularly for Orchidaceae. In this region are several genera that have a large number of endemic species that are in serious decline or edging towards extinction. Studies relating to diversity of orchids and their fungal partners (both mycorrhizal and non-mycorrhizal root associates) deserve more attention, as climate change and human induced decline in resilience of species in the wild is at an all-time high. Identification of mycorrhizal fungi (MF) via conventional seed baited-protocorms has limitations for large scale studies and its application for time-bound conservation projects. The paper describes the value of understanding fungal diversity in the roots of orchids at different stages of maturity. The first part of the study was a preliminary investigation mainly to identify culturable Rhizoctonia endophytes, and the second part looked at all life forms of available taxa together with associated soil characteristics. We isolated and identified 19 putative MF from 18 of the 50 taxa spread over an area of $250 \mathrm{sq}$. km, covering three life forms, growth phases of the orchid taxa, and habitat types. In the rest of the taxa, we were unable to detect any putative MF, but had varying numbers of non-mycorrhizal endophytes. We also found that diversity of putative MF was higher in plants from soils with the lowest P levels recorded. Putative mycorrhizal OTUs were predominantly from the Tulasnella lineage, followed by Ceratobasidium and Serendipita. Within a small subset of samples, a difference in colonised endophytes depending on the collection season was observed. In vitro germination studies using 10 OTUs of mycorrhizal fungi in 14 orchid species showed mostly generalist associations. When orchid seed and fungal sources were studied irrespective of habitat, life form, and distance from each other (orchid seed and fungal source), compatibility for symbiotic seed germination was observed in most cases. Issues with the identification of compatible MF and symbiotic system of seed germination are discussed.
\end{abstract}

Keywords: conservation; biodiversity hotspot; in vitro; orchid; mycorrhiza

\section{Introduction}

Madagascar harbours more than 1000 species of orchids, nearly $90 \%$ of which are endemic, adding to the island's international reputation as a unique biologically diverse resource. Many of these species are clustered within 'micro-hotspots' throughout the island, including the rocky domes (inselbergs) of the Central Highlands. Not only are the orchids of the Central Highlands largely inaccessible due to the formidable terrain, Madagascar itself is remote, further hindering study by specialists. The Itremo Massif within the Central Highlands is one such 'micro-hotspot', home to more than 86 orchid taxa of which the majority are endemic, and we have studied fungal diversity in 41 species in the past [1].

More than $80 \%$ of Madagascar's natural vegetation has been cleared or permanently altered [2] due to illegal mining and other anthropogenic activities [3]. Despite that region's rugged terrain, many orchids in the Central Highlands are exposed to several threats. 
Illegal collecting, pollinator decline, and fragmentation due to inbreeding depression are causing population decline in some orchids. These include several well-known species (e.g., Angraecum longicalcar) that cling to survival within the rocky landscape year after year in small, isolated populations. Many of these populations appear to be 'senile', i.e., lack biotic and/or abiotic factors necessary for generating spontaneous seedlings [4], and only a select few have received sufficient study.

Orchids are particularly vulnerable to decline in population resilience given their dependency on mycorrhizal fungi (MF) for seed germination [5] and further establishment [5-7]. To effectively conserve the orchids of the Central Highlands with respect to seed germination, more information is needed about the diversity and distribution of the fungal associates intimately tied to the orchid life cycle, and the abiotic factors needed by these fungi in each habitat (e.g., substrate $\mathrm{pH}$, nutrient levels). A logical first step is to identify culturable mycorrhizal fungi for establishing associations with orchids spanning different growth stages (protocorms, seedlings, mature plants).

The fungi that associate with photosynthetic orchids typically belong to the Rhizoctonia complex [8], which usually includes members of the Tulasnellaceae, Ceratobasidiaceae, and Sebacinales. These fungi are assumed to exist as free-living saprotrophs subsisting on organic matter that they decompose when moisture is available. As endophytes in living orchid tissues, they form dense intracellular masses of fungal hyphae (pelotons) that, once digested, release carbohydrates and nutrients to the orchid 'host'. Yet not all pelotonforming fungi are assignable to the Rhizoctonia complex. For example, species of Fusarium and Trichoderma have been acquired from pelotons of orchids in Ecuador [9], China [10], as well as Madagascar [11], but their physiological role(s) on orchid development has yet to be determined. Yagame et al. [12], however, did determine that at least one nonRhizoctonia basidiomycete (Coprinellus sp.) was capable of serving as an orchid mycorrhizal associate. Thus, the possibility exists that these lesser-known fungi may augment the orchid's mycotrophic needs. Given that MF are increasingly recognized as one of the most important ecological components influencing orchid distributions [13,14], studying the full breadth of fungal endophytes has merit for conservation.

This paper presents an overview of a wide range of fungal endophytes identified from 50 orchid species from the Central Highlands in Madagascar following a study spanning five years. These fungi include members of the Rhizoctonia complex as well as lesser-known groups. To verify that selected fungal endophytes were indeed mycorrhizal associates, symbiotic germination experiments were also carried out and results described. In addition to the sampling of fungi, soil from the habitats were assessed for soil $\mathrm{pH}$, nutrients $(\mathrm{N}, \mathrm{P}$, $\mathrm{K})$ and moisture content during both the rainy and dry season. In doing so, we attempted to correlate the fungal diversity observed to these abiotic components and how these factors have the potential to influence orchid distribution and growth stages. The major impediment for the study throughout the five-year period was the limited number of plant roots and seed capsules that could be collected due to the small population number of the taxa studied, and the restrictions imposed by government permits.

\section{Materials and Methods}

\subsection{Soil Analysis}

Soil/substrate samples were collected at several locations and consisted of soil and humus in the case of terrestrial habitats, and organic/inorganic debris on the surface of bark and in the cracks of rocks where epiphytic/lithophytic orchids were found. Single samples of soil were taken at each collection site. On return to Kew Madagascar Conservation Centre (KMCC), the collected samples were analysed using a LaMotte STH Series Combination Soil Testing Outfit (LaMotte, Chestertown, MD, USA). This provided quantitative data on the condition of the soil/substrate in the vicinity of each orchid sampled. Parameters tested were $\mathrm{pH}$, nitrate, phosphorous, and potassium. Organic content (humus) level was also tested, giving rise to a category value of $1-5$, where 1 is no organic content and 5 is very high organic content. 


\subsection{Fungal Isolation, Initial Identification, and Deposition}

In addition to the seven sites visited in 2013 [1] (dry season), seven further sites in the Central Highlands were visited in 2015 (rainy season) to collect orchid roots and seeds, some of the taxa collected are included in Figure 1. Single plants were sampled according to the collecting permit issued by the Madagascan government, whereby a maximum of five juvenile and five mature plants could be collected for each species. Material was imported to the UK and USA with all relevant permissions and authorizations, including CITES and phytosanitary certification. All root samples were placed in refrigeration $\left(4-6{ }^{\circ} \mathrm{C}\right)$ immediately upon arrival at Royal Botanic Gardens, Kew (RBG Kew), and Illinois, USA, from Madagascar after collecting. Samples were promptly processed for isolating fungi present in the juvenile and mature phase plant roots. This process continued for 10 days while viable pelotons were available from healthy roots. Colonization of mycorrhiza as pelotons in the cortical region of root sections was scored as percentage of colonized root cortical cells, observed in cross-section under a dissection stereomicroscope, for all three life-forms: epiphtytic, lithophytic, and terrestrial. From root sections with visible colonization where pelotons were observed, either single pelotons or clumps of cells were teased out using a sterile scalpel assisted by dissection microscope and plated directly onto FIM [15] supplemented with $100 \mathrm{mg} / \mathrm{L}$ streptomycin sulphate [16] to isolate and identify the peloton-forming fungi. Culturing of the pelotons was achieved in vitro according to Zettler et al. [17] and Yokoya et al. [1].

After 1-4 days, hyphal tips that were observed emerging from cortical cells and/or pelotons under a dissection microscope were subcultured to FIM (RBG Kew) or Potato Dextrose Agar (PDA, Difco ${ }^{\mathrm{TM}}$, Becton, Dickinson and Co., Sparks, MD, USA) (Illinois) using a sterile scalpel. To safeguard the mycorrhizal OTUs for the purposes of future work (e.g., symbiotic seed germination) and long-term conservation, they were cryopreserved in vapour phase of liquid nitrogen, as described by Batty et al. [18].

\subsection{Molecular Identification of Fungi by ITS Sequencing}

Pure cultures of fungi were positively identified using DNA sequencing as described in Yokoya et al. [1]. Briefly, DNA from fresh mycelia was extracted in 96-well plates using the Extract-N-Amp ${ }^{\text {TM }}$ Plant Tissue PCR Kit (Sigma Aldrich, UK). PCR amplification of the ITS region using primer ITS1F with ITS4 and ITS1 with ITS4-tul [19-21] was followed by Sanger sequencing using the same forward and reverse primers. The forward and reverse sequences were checked for accuracy and consensus and compared with database sequences using BLAST (National Center for Biotechnology Information, Bethesda, MD, USA). Sequences were aligned and grouped into operational taxonomic units (OTUs) based on a conservative similarity threshold of 95\% (Supplementary Materials). Representative sequences of each OTU were used to re-query the GenBank database using BLAST.

\subsection{Seed Germination}

Seeds from 14 orchid taxa covering three life forms were cultured in vitro with putative MFs from different life forms of orchids. On average, 5000-8000 seeds of each orchid taxon were used with 10 different OTUs of putative mycorrhizal fungi. Seeds were sown in vitro on standard oatmeal agar (OMA; $7 \mathrm{~g}$ agar, $2.5 \mathrm{~g}$ rolled oats, $1 \mathrm{~L}$ water) as a control medium tested against OMA inoculated with different fungal isolates. Seed germination data were collected up to 12 weeks to ensure uniformity in data collecting, although different life forms of orchids were studied. Seed germination and protocorm development stages were assigned as defined by Yamazaki and Miyoshi [22]. Stages 3-4 (protocorm) and leaf forming Stage 5 were the main responses analysed.

\subsection{Data Analysis}

The number of germinated seeds and number of seeds that developed to Stage 5 were analyzed using the Kaplan-Meier statistical test using the Survival package (R statistical software, Version R 3.0.1, The R Foundation for Statistical Computing) as used by 
McNair et al. [23,24]. At 24 weeks, the germination analysis was carried out on each stage using $\mathrm{Chi}^{2}$ (Microsoft Excel, Microsoft, Reading, UK). The program PVCLUST was used in $\mathrm{R}$ to produce a hierarchical cluster analysis using the Ward method.

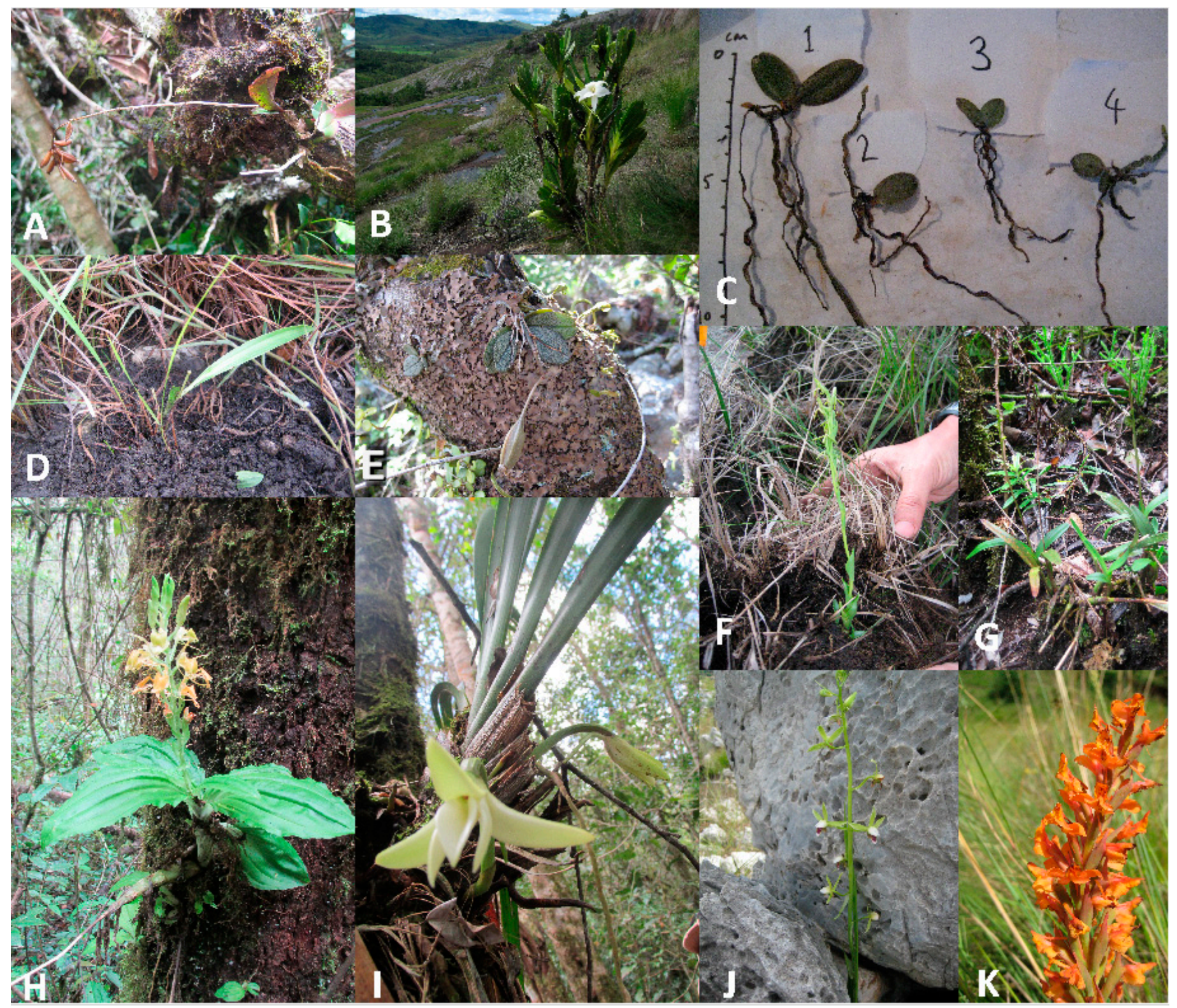

Figure 1. Images of some of the orchids studied. (A)_Polystachya sp.; (B)—Angraecum sororium; (C)—Aerangis fastuosa (growth phase of plants collected); (D)_Habenaria sp.; (E)_Aerangis punctata; (F)—Habenaria simplex; (G) —Polystachya concreta; (H)_Liparis ochracea; (I)_Jumellea pachyceras; (J)_Eulophia plantaginea; (K)_Disa incarnata.

\section{Results}

Majority of putative MFs collected during dry season were from juvenile plants while all MFs collected during rainy reason were from mature plants. Out of six mature plants yielding putative MFs, five of them were terrestrial orchid taxa sampled in both dry and rainy seasons (Tables 1 and 2). The remaining one was an epiphyte during rainy season (Table 2). However, six out of seven taxa yielding putative MFs collected during the dry season were juvenile plants (Table 1). A full list of Rhizoctonia MFs is included in the Supplementary Materials. 
Table 1. Life form and growth phase of orchids collected during dry season and OTUs identified.

\begin{tabular}{|c|c|c|c|c|c|c|c|c|}
\hline Taxa (Epiphytes) & $\begin{array}{l}\text { Growth } \\
\text { Phase }\end{array}$ & OTU & Taxa (Lithophytes) & $\begin{array}{l}\text { Growth } \\
\text { Phase }\end{array}$ & OTU & Taxa (Terrestrial) & $\begin{array}{l}\text { Growth } \\
\text { Phase }\end{array}$ & OTU \\
\hline Aerangis sp. 1 & Juvenile & cer1 & Aerangis ellisii & Juvenile & cer2 & Benthamia sp. & Mature & - \\
\hline \multirow{2}{*}{ Aerangis sp. 2} & Juvenile & cer3 & & Mature & - & B. cinnabarina & Mature & tul2 \\
\hline & Mature & - & Angraecum coutrixii & Juvenile & - & B. glaberrima & Mature & - \\
\hline Aerangis ellisii & Mature & - & & Mature & - & B. rostrata & Juvenile & - \\
\hline Aerangis punctata & Juvenile & cer1, tul7 & Angraecum longicalcar & Mature & - & Calanthe sp. & Mature & - \\
\hline Aeranthes sp. & Mature & - & $\begin{array}{l}\text { Angraecum } \\
\text { magdalenae }\end{array}$ & Juvenile & tul1 & Cynorkis gibbosa & Mature & - \\
\hline Angraecum sp. 1 & Juvenile & - & \multirow{2}{*}{ Angraecum protensum } & Juvenile & tul3 & \multirow{4}{*}{ Cynorkis purpurea } & \multirow{4}{*}{ Juvenile } & cer4 \\
\hline Angraecum sp. 2 & Juvenile & - & & Mature & - & & & ser1 \\
\hline Angraecum coutrixii & Mature & - & $\begin{array}{c}\text { Angraecum } \\
\text { rutenbergianum }\end{array}$ & Juvenile & - & & & tul3 \\
\hline $\begin{array}{l}\text { Angraecum } \\
\text { protensum }\end{array}$ & Juvenile & - & Angraecum sororium & Juvenile & - & & & tul4 \\
\hline $\begin{array}{c}\text { Angraecum } \\
\text { rutenbergianum }\end{array}$ & Mature & - & Bulbophyllum sp. 1 & Mature & - & Disa incarnata & Mature & - \\
\hline Bulbophyllum sp. 2 & Juvenile & - & Oeceoclades calcarata & Mature & - & Eulophia macra & Mature & - \\
\hline Bulbophyllum sp. 3 & Mature & - & & & & Graphorkis concolor & Mature & - \\
\hline Bulbophyllum sp. 4 & Mature & - & & & & Habenaria sp. & Mature & - \\
\hline Bulbophyllum sp. 5 & Mature & - & & & & Satyrium trinerve & Mature & - \\
\hline Jumellea densefoliata & Juvenile & - & & & & Tylostigma sp. & Mature & tul5 \\
\hline Polystachya concreta & Juvenile & ser2, ser3 & & & & T. nigrescens & Mature & tul6 \\
\hline P. cultriformis & Juvenile & - & & & & T. tenellum & Juvenile & tul4 \\
\hline
\end{tabular}

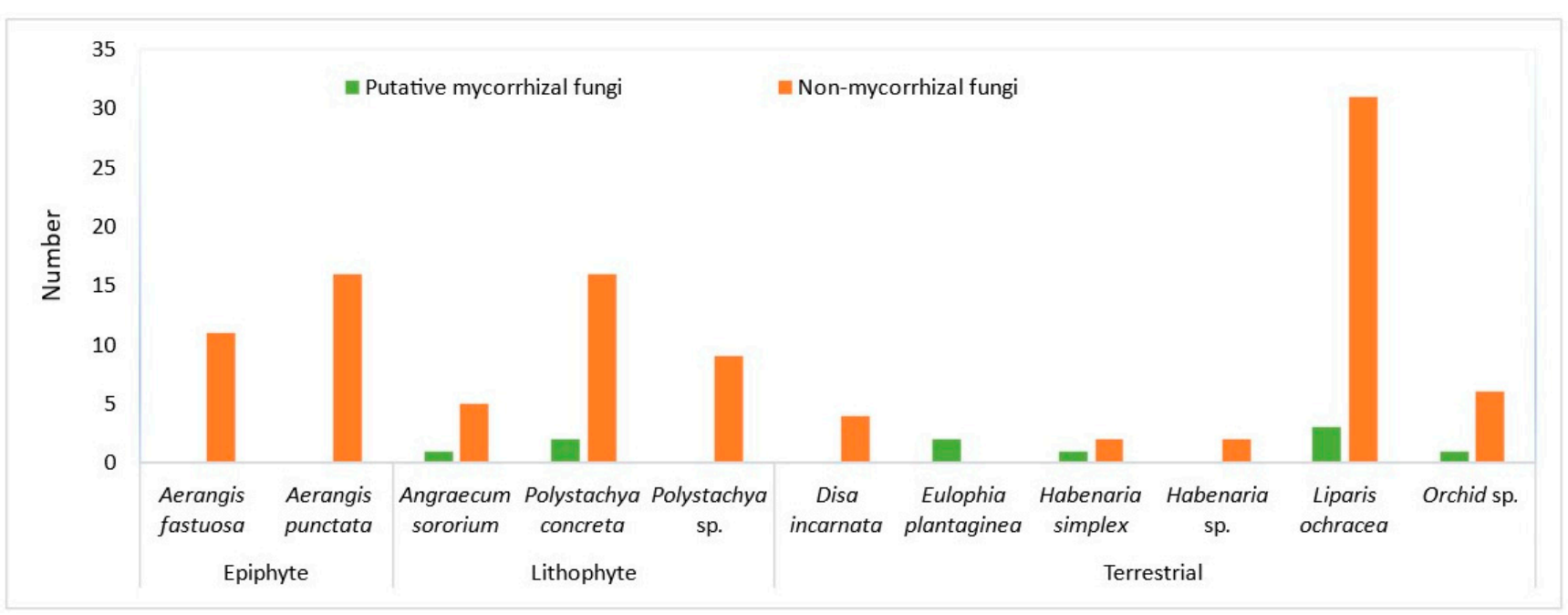

Figure 2. Number of putative mycorrhizal and non-mycorrhizal fungi from epiphytic, lithophytic, and terrestrial taxa studied during rainy season. 
Table 2. Soil data collected during the rainy season from 12 orchids representing three life forms (Figure 2).

\begin{tabular}{|c|c|c|c|c|c|c|c|c|}
\hline Host & $\begin{array}{l}\text { Growth } \\
\text { Phase }\end{array}$ & Life Form & OTU & $\mathrm{pH}$ & $\begin{array}{l}\text { Nitrogen } \\
\text { (ppm) }\end{array}$ & $\begin{array}{l}\text { Phosphorus } \\
\text { (ppm) }\end{array}$ & $\begin{array}{l}\text { Potassium } \\
\text { (ppm) }\end{array}$ & Soil Comments \\
\hline Aerangis fastuosa & Seedling & Epiphyte & - & 6.8 & 20 & 37 & 50 & $\begin{array}{l}\text { Very little soil. Live moss } \\
\text { and dead leaves }\end{array}$ \\
\hline Angreacum punctata & Seedling & Epiphyte & - & 6.8 & 20 & 37 & 50 & $\begin{array}{l}\text { Very little soil. Live moss } \\
\text { and dead leaves }\end{array}$ \\
\hline Angraecum sororium & Seedling & Lithophyte & - & 5.2 & 20 & 12 & 150 & Dark, moist, live grass \\
\hline Disa incarnata & Mature & Terrestrial & - & 5 & 30 & 5 & 70 & Dry, brown, sandy \\
\hline Eulophia plantaginea & Mature & Terrestrial & tul9, tul10 & 5.2 & 30 & 5 & 70 & Dry, brown, sandy \\
\hline Habenaria sp. & Juvenile & Terrestrial & - & 5.2 & 20 & 5 & 50 & $\begin{array}{l}\text { Dark, moist, grass } \\
\text { and moss }\end{array}$ \\
\hline Habenaria simplex & Mature & Terrestrial & tul5 & 5 & 30 & 5 & 70 & Dry, brown, sandy \\
\hline Jumellea pachyceras & Mature & Terrestrial & - & 5 & 30 & 37 & 50 & $\begin{array}{l}\text { Lots of grass roots, wood } \\
\text { and mulch. Dark, moist }\end{array}$ \\
\hline Liparis ochracea & Mature & Terrestrial & $\begin{array}{l}\text { tul12, cop1, } \\
\text { cop2 }\end{array}$ & 6.8 & 20 & 37 & 50 & $\begin{array}{c}\text { Very little soil. Live moss } \\
\text { and dead leaves }\end{array}$ \\
\hline Orchid sp. & Mature & Terrestrial & tul5 & 6.8 & 30 & 12 & 65 & Heavy clay. Dark \\
\hline Polystachya concreta & Mature & Epiphyte & tul5, tul 13 & 5 & 50 & 12 & 175 & $\begin{array}{l}\text { Dark, slightly moist, } \\
\text { some grass roots }\end{array}$ \\
\hline Polystachya sp. & Seedling & Epiphyte & - & 5 & 50 & 12 & 175 & $\begin{array}{l}\text { Dark, slightly moist. } \\
\text { some gr ass roots }\end{array}$ \\
\hline
\end{tabular}

\subsection{Orchid MF Collected during Dry Season}

Orchid MF of all three genera of the Rhizoctonia complex were identified from root collections. This consisted of seven Tulasnella, four Ceratobasidium, and one Serendipita, as summarised in Table 1. Putative MFs were obtained from only juvenile plants in epiphytes and lithophytes except Polystachya concreta, however, fungal colonization was observed from the pelotons extracted from the collected roots of mature epiphytes and lithophytes.

\subsection{Orchid MF Collected during Rainy Season}

Tulasnella and Serendipita OTUs were identified from root collections during the rainy season from lithophytes and terrestrials (Table 2). Two putative MFs, Tulasnella, were obtained from juvenile samples of Polystachya concreta, while one MF obtained from mature plants in the dry season. However, in all other cases, pelotons grown in culture failed to identify any putative MFs.

The majority of the orchid species that yielded MF during rainy season were terrestrial taxa (Table 2, Figure 2). MFs were not obtained from the two terrestrial taxa (Disa incarnata and Habenaria sp.) out of six taxa studied. Both epiphytes studied (Aerangis fastuosa and A. punctata) and one lithophyte out of three taxa studied, Polystachya sp, yielded no MFs (Figure 2).

\subsection{Soil Characteristics and Fungal Diversity in Orchids Collected during Rainy Season}

More non-mycorrhizal fungi were found in plants grown at lower nitrogen content (Figure 3A). Except in Liparis ochracea, MF were found in plants grown at phosphorus content of $12 \mathrm{ppm}$ or below (Figure 3B). In orchids from soil with $37 \mathrm{ppm}$ of phosphorus, either no MFs or greater numbers of non-MF were identified. In Liparis ochracea, the diversity of fungi was significantly different compared to all other orchids studied (Supplementary Materials). Tulasnella (tul12) and Coprinellus sp. and C. disseminatus (putative MF) were found in addition to several dark septate endophytes and other endophytes in this terrestrial species. The fungal diversity in Aerangis punctata is presented as a comparison (Supplementary Materials). 


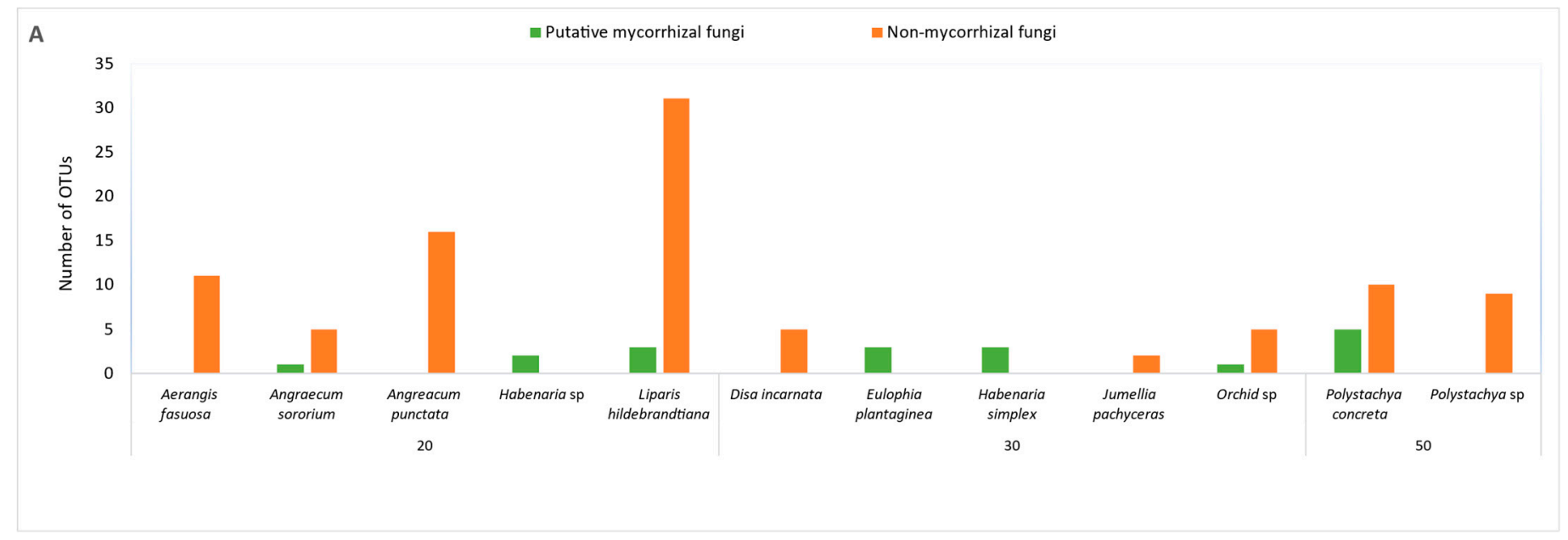

B
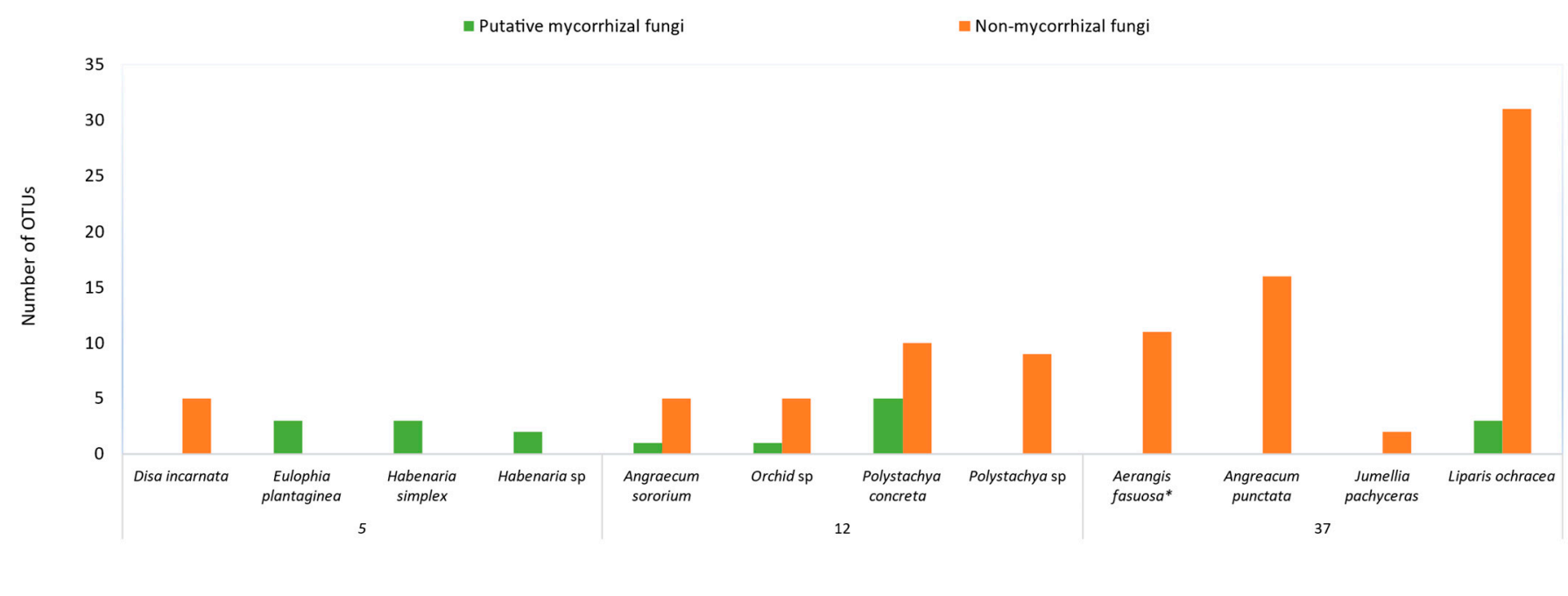

Figure 3. Fungal diversity, both putative mycorrhizal and non-mycorrhizal, in 12 orchids collected during the rainy season relative to nitrogen $(\mathbf{A})$ and phosphorus $(\mathbf{B})$ content in the soil.

Immediately after rains, when L. ochracea roots were collected and fungi were identified, the fungal diversity data shows an interesting picture. The plants were found in shady, moist forest with moss and litter as the substrate with very little soil (pH 6.2). Many of the orchids collected during this period were from soil with comparatively low phosphorus content (5-12 ppm), while substrate associated with L. ochracea had comparatively higher phosphorus content (37 ppm).

Aerangis punctata was collected in both dry and rainy seasons and showed seasonal variability in the recruitment of fungi. The species yielded MFs Ceratobasdium and Tulasnella (OTUcer1 and OTUtul7) during the dry season (Table 1), while no orchid MF were isolated from the rainy season collection (Supplementary Materials). Dothideomycetes, Lophiostoma, Pleosporales, Capronia, Cladiophialophora, and Virgaria nigra were the fungi isolated during the dry season, while 15 completely different non-MF endophytes were identified in the rainy season. Roots with even higher colonisation sometimes failed to yield MF. Even where pelotons were present, they were not be viable, because they are seasonally active.

Tulasnella was the only MF lineage from both Angraecum magdalenae and A. protensum. Angraecum sororium sp. collected during the rainy season also yielded tul5, Tulasnella MF (Table 2). Although this is a small selection of Angraecum taxa, in the majority of our samples, we observed pelotons in $<60 \%$ of the cortical cells, always on the side of the root that was in close contact with the substrate. In the several species of Bulbophyllum that were 
collected, none of the roots yielded any MF. Eulophia plantaginea and Polystachya concreta yielded two Tulasnella OTUs, both from soil with low levels of phosphorus (5 and $12 \mathrm{ppm}$, respectively) (Table 2, Figure 3B). Our findings show that most of the MF OTUs were found at the tip of the roots.

\subsection{Symbiotic Seed Germination}

Diverse orchids were sown with the available range of MFs to see how compatible they are to produce symbiotic seedlings. However, MFs from all 14 seed sources were not available for this study (Table 3). Nine out of 14 orchid taxa were able to germinate and develop to Stage 5 (seedling stage, Figure 4) with at least one of the 10 selected isolates. Aerangis ellisii and Cynorkis purpurea were germinated by their own MF (in bold in Table 3). In a previous study as part of this project, Yokoya et al. [1] showed MFmediated symbiotic seed germination in Tylostigma nigrescens. In the lithophytic Angraecum rutenbergianum, the Tulasnaella OTUs tul1 (from A. magdalenae, a lithophyte) and tul2 (from the terrestrial Benthamia cinnabarina) were able to facilitate germination to Stage 5, suggesting that germination can be promoted by isolates of distant species of orchid spanning different life forms. The epiphytic Bulbophyllum peyrotii seeds reached seedling stage (Stage 5) with cer1 from Cynorkis purpurea (terrestrial). Both species of Habenaria, from montane grassland, produced seedlings with orchid MF from Aerangis sp. (cer3) collected from gallery forest.

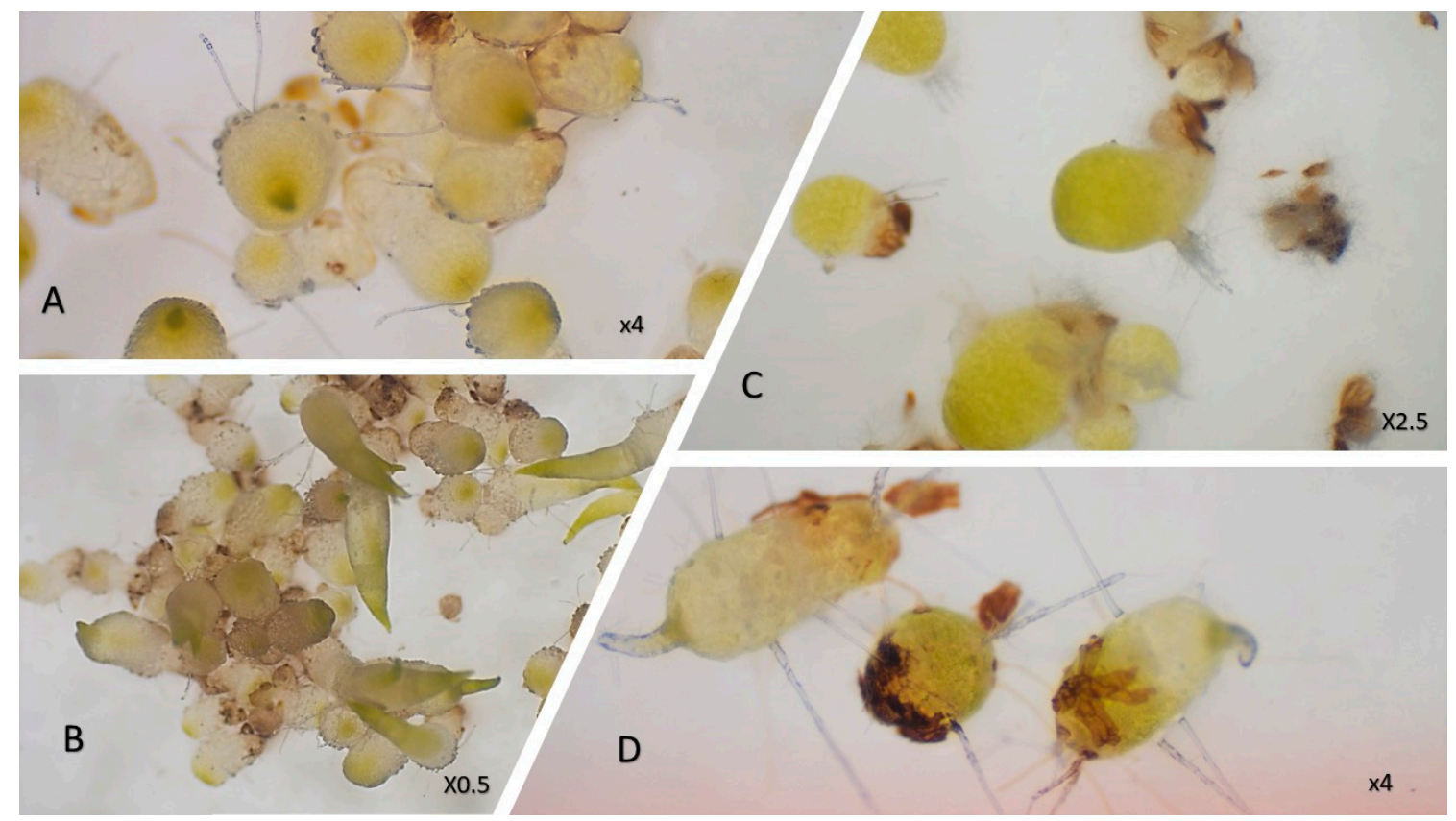

Figure 4. Symbiotic seed germination in vitro of Bulbophyllum peyrotii (A,B), Angarecum rutenbergianum (C), and Tylostigma nigrescens (D).

Development to the protocorm stage alone was not regarded as complete germination induced by the presence of fungi, given that water imbibition and other factors (e.g., nutrient requirements for seed germination fulfilled by OMA components) may also be involved. Embryos in many the orchids studied here developed to the protocorm stage on oatmeal agar controls without fungal inoculation. 


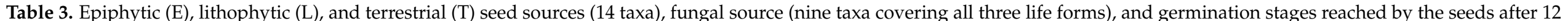
weeks. Number 5 represents seedling development (bold number 5 represents germination with own mycorrhizal fungus).

\begin{tabular}{|c|c|c|c|c|c|c|c|c|c|c|c|}
\hline & cer1 & cer2 & cer3 & ser1 & ser2 & tul1 & tul2 & tul3 & ser3 & tul5 & Oatmeal Control- Most \\
\hline OTU and Fungal Source & $\begin{array}{l}\text { Aerangis } \\
\text { punctata } \\
\text { (E) }\end{array}$ & $\begin{array}{l}\text { Aerangis } \\
\text { ellisii (E) }\end{array}$ & $\begin{array}{l}\text { Aerangis } \\
\text { sp. (E) }\end{array}$ & $\begin{array}{l}\text { Cynorkis } \\
\text { purpurea }(\mathrm{T})\end{array}$ & $\begin{array}{l}\text { Polystachya } \\
\text { concreta (E) }\end{array}$ & $\begin{array}{l}\text { Angraecum } \\
\text { magdalenae } \\
\text { (L) }\end{array}$ & $\begin{array}{l}\text { Benthamia } \\
\text { cinnabarina } \\
\text { (T) }\end{array}$ & $\begin{array}{l}\text { Cynorkis } \\
\text { purpurea }(\mathrm{T})\end{array}$ & $\begin{array}{l}\text { Polystachya } \\
\text { concreta (E) }\end{array}$ & $\begin{array}{l}\text { Tylostigma sp. } \\
\text { (T) }\end{array}$ & $\begin{array}{l}\text { Advanced Stage (Total } \\
\text { Germination Percentage } \\
\text { of Stages 2-4) }\end{array}$ \\
\hline \multicolumn{12}{|l|}{ Seed source } \\
\hline Aerangis ellisii (E)* & - & 5 & 5 & - & - & - & - & - & - & & 0 \\
\hline Cynorkis purpurea $(\mathrm{T}) * *$ & 5 & 5 & 5 & 5 & 5 & 4 & - & 5 & 5 & 5 & $4(74)$ \\
\hline Angraecum coutrixii $(\mathrm{L})$ & - & - & 3 & 3 & - & 3 & - & - & - & - & $2(2.1)$ \\
\hline Habenaria ambositrana $(\mathrm{T})$ & 4 & 4 & 5 & 4 & - & - & 4 & - & 4 & - & $4(18.2)$ \\
\hline Benthamia cinnabarina $(\mathrm{T})$ & 4 & - & 4 & 4 & - & - & - & 5 & 4 & - & $4(14.8)$ \\
\hline Disa incarnata $(\mathrm{T})$ & 4 & - & 4 & - & 4 & 4 & 4 & 4 & - & - & $4(10.8)$ \\
\hline Satyrium trinerve $(\mathrm{T})$ & - & - & 4 & - & 3 & - & 3 & - & - & - & $3(19.2)$ \\
\hline Tylostigma nigrescens $(\mathrm{T})$ & 4 & - & 4 & 4 & 4 & - & 5 & 4 & - & - & $3(21.4)$ \\
\hline Aerangis citrata $(\mathrm{E})$ & - & - & 4 & - & - & 3 & - & - & - & - & $1(0)$ \\
\hline Bulbophyllum peyrotii (E) & - & - & - & 5 & 4 & - & 4 & 4 & - & - & $4(98)$ \\
\hline $\begin{array}{c}\text { Angraecum } \\
\text { rutenbergianum (E/L) }\end{array}$ & - & - & - & 3 & - & 5 & 5 & 3 & - & - & $2(5.1)$ \\
\hline Tylostigma sp. (T) & 4 & - & 4 & 4 & 4 & 5 & 5 & 4 & 4 & - & $4(37.8)$ \\
\hline
\end{tabular}

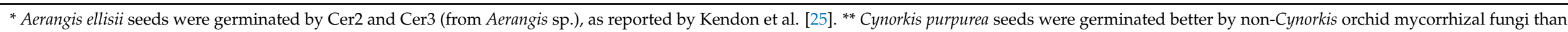
own mycorrhizal fungus (ser1), as reported by Rafter et al. [24]. 


\section{Discussion}

This study, encompassing three long-distance trips to the Central Highlands of Madagascar during a five-year period, documents, for the first time, fungal diversity associated with roots of 50 different taxa found on rocks (lithophytes), on host trees (epiphytes) and in soil (terrestrials). In addition, we noted some correlations between fungal diversity and substrate nutrients $(\mathrm{N}, \mathrm{P}, \mathrm{K}), \mathrm{pH}$, or dry vs. rainy season, suggesting patterns in the environmental conditions that these orchids and their fungi may require for their survival in situ. While our sampling was limited, we did reveal several preliminary findings that we think warrant more study. For example, during the dry season, five of the epiphytes and lithophytes sampled (Aerangis, Angraecum sp.) harboured mycorrhizal OTUs assignable to Ceratobasidium and Tulasnella that were present in juvenile plants, but none were detected in roots of mature plants (Table 1). It is conceivable that these juvenile-plant-derived fungi were root-inhabiting 'relics' that played a role in seed germination and early seedling development, and simply persisted in the root system at the time they were collected.

As to why roots from the mature stages were devoid of fungi, it is not known but may be attributed to a number of factors [5]. For example, Dycus and Knudson [26] concluded that the velamen and exodermis in aerial roots of epiphytic orchids serve as a barrier to the uptake of water and certain solutes including available $\mathrm{N}$ and P. However, passage into the cortex was noted through root surfaces in contact with the substratum (bark, clay pots) where cells in the velamen layer were notably thinner. Bayman et al. [27] noted that fungal pelotons in the cortical region of epiphytic orchid roots were positioned closest to the bark substrate, suggesting that this is the entry point for fungal colonization into the root. During our sampling in Madagascar, the majority of roots from epiphytes and lithophytes that were acquired were in close contact with the substratum. Thus, we hypothesize that the lack of fungi in samples from mature epiphytes and lithophytes may be attributed to a reduced dependency on MF of mature plants, which would already have developed root systems that are well associated with their substrate. Conversely, juvenile lithophytes and epiphytes might be more dependent on water and nutrient uptake via their mycorrhizal associates, particularly during the dry season. Although the sample sizes in this study are small, our work provides some evidence that juvenile epiphytes are more reliant on their root symbionts more during the dry season (as shown in Aerangis spp. and Angraecum magdalenae).

In contrast, roots of terrestrials have a reduced velamen layer and remain underground where access to moisture is more readily available, and it is not surprising that even mature terrestrials (Benthamia, Tylostigma) harboured mycorrhizal OTUs (Tulasnella) during the dry season (Table 1). However, deeper into the dry season, most terrestrials undergo dormancy as drought-resistant tubers, and would be less dependent on MF during this period. There were several terrestrial species collected in the dry season that had good root colonisation but failed to yield MF in culture, which could be explained by the imminent dormant period. The emerging picture is that terrestrial orchids harbour MFs throughout their life cycle but are apparently not associated with them during dormancy, while lithophytes and epiphytes are more reliant on MF during the juvenile stages of development but did not have detectable MF in mature specimens. From the standpoint of conservation, it would be suggested that reintroduction of symbiotically grown seedlings of any life form should be performed during the rainy season as the best option to ensure that there is adequate moisture for both organisms (seedlings and fungi) leading up to establishment. Correlating seasonality with orchid growth stages and the fungi that are involved has the potential to render conservation methods more effective.

Availability of compatible fungi within the ecosystem underpins the distribution of orchids, irrespective of their life forms. Conversely, resilience of the fungal populations in the ecosystem may depend on the abundance of host plants in a given population. It has been shown that these fungi persist within the orchid even after the germination event. Shrinking orchid populations will directly contribute to declining fungal diversity and density, and vice versa. Our limited sampling of a large number of orchid species is not 
fully sufficient to prove this point. Analysing the influence of ecological constraints and the relationship between orchids and orchid MF is highly relevant. Plants harbouring MF displayed more advanced growth attributes, as reported in the temperate orchid Cephalanthera rubra [28], although the isolated mycorrhizal OTUs were not successful in germinating the C. rubra seeds. This shows orchids recruit and harbour some of the MF, but not all of them contribute to successful seed germination.

Two species studied in detail in in vitro germination studies, Aerangis ellisii (epiphyte/lithophyte) and Cynorkis purpurea (terrestrial), displayed contrasting results under in vitro symbiotic germination conditions. C. purpurea turned out to be a generalist [24] while A. ellisii was a specialist [25] in terms of compatible mycorrhizal associates. Seeds of Cynorkis purpurea germinated successfully with its own MF, but more advanced seedling development occurred with MF sourced from other orchids. Specificity varies among species, in terrestrial orchids [29-32]; in neotropical, epiphytic orchids [33-38]; and in lithophytes [25]. It is argued that generalist orchids might be more prevalent in nutrient-poor or drought-stressed niches [31]. Without reintroduction trials, in vitro seed germination supported by MF (Table 3) is not a fully reliable test, as compatible fungi may differ in the wild environment. Future studies using different growth phases of orchids offer opportunities to identify compatible MF for seed germination that can potentially be used for conservation. Screening of orchids to culture and identify lineages of a wide spectrum of fungi will help support in vitro germination research and therefore improve the conservation prospects of these species.

Considering that $80 \%$ of Madagascar's natural vegetation has been cleared or permanently altered [2] due to illegal mining and other anthropogenic activities [3], documenting the nutrients (N, P, K) present in orchid substrata was another focus of our study. This is especially true in the Central Highlands, where the controlled burning of tapia forests and grasslands can have a profound negative impact on vegetation [39] and presumably soil nutrients. Not surprisingly, more is currently known about the impact of nutrients on terrestrial orchids. Compared to other plants, orchids seem to favor organic forms of $\mathrm{N}$ over inorganic forms [40], and higher levels of the latter may actually inhibit growth or lead to toxicity [41,42]. Similarly, Jacquemyn et al. [31] suggested that generalist orchids might be more prevalent in nutrient-poor or drought-stressed niches. Recently, Figura et al. [43] determined that orchids inhabiting oligotrophic habitats were more sensitive to nitrate levels compared to those found in eutrophic habitats. They also reported that nitrate levels had a negative impact on orchid distribution by inhibiting seed germination. In our study, $\mathrm{N}$ levels (ppm) were relatively consistent among the substrata for epiphytes, lithophytes, and terrestrials alike (Table 2), possibly because our sampling took place in more remote areas with little intensive agriculture. Given the findings reported by other researchers, we advocate that future conservationists focus their efforts on regions of the Itremo Massif that remain free of human activity as much as possible. Analysis of soil/supporting substrate for all life forms of orchids to enable successful repatriation back to the wild must also be included in the list of future research priorities.

While we still know fairly little about how nutrients in the landscape affect orchid distribution, even less is known about the role of nutrient sources (mineral or organic) on orchid MF. Studies by Nurfadilah et al. [44], however, explored the impact of C, N, and P on the growth of all three major genera of orchid mycorrhizal associates-Ceratobasidium, Sebacina, and Tulasnella - and determined that these fungi exploited a 'wide and variable menu' of $\mathrm{C}, \mathrm{N}$, and P sources. Additionally, all three genera utilised ammonium as a source of inorganic N. In tropical regions that are subjected to rainy and dry seasons, nutrient levels could potentially fluctuate and have the potential to influence the distribution and survival of orchid mycorrhizal associates and the seedlings they support. In the present study, we attempted to correlate nutrient levels with the presence of MF and non-MF and seasonality. Although highly preliminary, our findings seem to suggest that lower $\mathrm{P}$ content (12 ppm or below) may promote greater colonisation of orchid roots by Rhizoctonia fungi compared to the non-mycorrhizal endophytes (Figure 3B). To our knowledge, this 
potentially important aspect of orchid ecology has not been addressed in the literature and warrants study.

\section{Conclusions}

Diverse orchids of Central Highlands harbour Tulasnella lineage of MF as the dominant group. The majority of non-juvenile samples of epiphytic and lithophytic orchids failed to yield any culturable putative MF during the dry season. This means that seed baiting, a time-consuming and labour-intensive method, cannot be completely ruled out as an alternative route to identify the compatible mycorrhizal associates as part of a longer duration conservation action planning for orchids that are at the brink of extinction. On the other hand, terrestrial species yielded MF during both dry and rainy seasons from all growth stages. We also found that putative MFs isolated from closely related or distant taxa can initiate germination of seeds in vitro. The implications of using putative MF from distantly related orchids is a point to be explored further, as it brings up the question of whether it is critically necessary to pursue the original mycorrhizal associate, particularly when isolation and culture of an endangered orchid's own MF becomes difficult due to them having been depleted to small numbers in the wild. In addition to the compatibility assessment for mycorrhizal symbionts, reintroduction/reinforcement in the wild requires a detailed study on soil characteristics. Both the fungus and orchid collected from a specific habitat must be studied for their resilience in supporting each other during and after reintroduction to achieve high survival rates of the orchid-fungus complex and attain sustainable success in the conservation of rare orchids.

Supplementary Materials: The following are available online at https:/ / www.mdpi.com/1424-2 818/13/2/96/s1, Table S1: Closest match in Genbank of mycorrhizal and non-mycorrhizal fungi identified from Liparis ochracea; Closest match in Genbank of mycorrhizal and non-mycorrhizal fungi identified from Aerangis punctata; Orchid taxa studied, accession of putative mycorrhizal fungi isolated, name of OTUs and sequence.

Author Contributions: Conceptualization, V.S. and L.W.Z.; methodology, V.S., K.Y., L.W.Z.; validation, K.Y., V.S.; formal analysis, K.Y., J.B., J.P.K., A.S.J.; investigation, K.Y., L.W.Z., L.R., J.P.K., J.B., A.S.J., V.S., E.S.; resources, V.S., L.W.Z.; data curation, J.P.K., V.S.; writing-original draft preparation, V.S.; writing-review and editing, K.Y., L.W.Z., L.R., J.P.K., J.B., A.S.J., V.S.; supervision, V.S., L.W.Z.; project administration, V.S., L.W.Z.; funding acquisition, V.S., L.W.Z. All authors have read and agreed to the published version of the manuscript.

Funding: We acknowledge the assistance received from Jacky Andriantiana (Parc Botanique et Zoologique de Tsimbazaza), Edward Jones (Royal Botanic Gardens, Kew), and Amanda Wood (Illinois College) for field support during the collection. The technical support from Margaret Ramsay, Ebrailon Masetto, and James Pickering (Royal Botanic Gardens, Kew) is also much appreciated.

Institutional Review Board Statement: Not Applicable.

Informed Consent Statement: Not Applicable.

Data Availability Statement: Publicly available datasets were analyzed in this study.

Acknowledgments: The authors acknowledge funding from the Sainsbury Orchid Project, BenthamMoxon Trust, and Illinois College.

Conflicts of Interest: The authors declare no conflict of interest.

\section{References}

1. Yokoya, K.; Zettler, L.W.; Kendon, J.P.; Bidartondo, M.I.; Stice, A.L.; Skarha, S.; Corey, L.L.; Knight, A.C.; Sarasan, V. Preliminary findings on identification of mycorrhizal fungi from diverse orchids in the Central Highlands of Madagascar. Mycorrhiza 2015, 25, 611-625. [CrossRef]

2. Alvarado, S.T.; Buisson, E.; Rabarison, H.; Rajeriarison, C.; Birkinshaw, C.; Ii, P.P.L. Comparison of plant communities on the Ibity and Itremo massifs, Madagascar, with contrasting conservation histories and current status. Plant Ecol. Divers. 2014, 7, 497-508. [CrossRef] 
3. Carrasco, J.; Price, V.; Tulloch, V.; Mills, M. Selecting priority areas for the conservation of endemic trees species and their ecosystems in Madagascar considering both conservation value and vulnerability to human pressure. Biodivers. Conserv. 2020, 29, 1841-1854. [CrossRef]

4. Rasmussen, H.N.; Dixon, K.W.; Jersáková, J.; Těšitelová, T. Germination and seedling establishment in orchids: A complex of requirements. Ann. Bot. 2015, 116, 391-402. [CrossRef]

5. Rasmussen, H.N.; Rasmussen, F.N. Orchid mycorrhiza: Implications of a mycophagous lifestyle. Oikos 2009, 118, 334-345. [CrossRef]

6. Cameron, D.D.; Leake, J.R.; Read, D.J. Mutualistic mycorrhiza in orchids: Evidence from plant-fungus carbon and nitrogen transfers in the green-leaved terrestrial orchid Goodyera repens. New Phytol. 2006, 171, 405-416. [CrossRef] [PubMed]

7. Waterman, R.J.; Bidartondo, M.I.; Stofberg, J.; Combs, J.K.; Gebauer, G.; Savolainen, V.; Barraclough, T.G.; Pauw, A. The Effects of Above- and Belowground Mutualisms on Orchid Speciation and Coexistence. Am. Nat. 2011, 177, E54-E68. [CrossRef] [PubMed]

8. Dearnaley, J.D.W.; Martos, F.; Selosse, M.A. 12 Orchid Mycorrhizas: Molecular Ecology, Physiology, Evolution and Conservation Aspects. In Fungal Associations. The Mycota (A Comprehensive Treatise on Fungi as Experimental Systems for Basic and Applied Research); Hock, B., Ed.; Springer: Berlin/Heidelberg, Germany, 2012; Volume 9. [CrossRef]

9. Novotná, A.; Benítez, Á.; Herrera, P.; Cruz, D.; Filipczyková, E.; Suárez, J.P. High diversity of root-associated fungi isolated from three epiphytic orchids in southern Ecuador. Mycoscience 2018, 59, 24-32. [CrossRef]

10. Jiang, J.; Zhang, K.; Cheng, S.; Nie, Q.; Zhou, S.-X.; Chen, Q.; Zhou, J.; Zhen, X.; Li, X.T.; Zhen, T.W.; et al. Fusarium oxysporum KB-3 from Bletilla striata: An orchid mycorrhizal fungus. Mycorrhiza 2019, 29, 531-540. [CrossRef] [PubMed]

11. Zettler, L.W.; Rajaovelona, L.; Yokoya, K.; Kendon, J.P.; Stice, A.L.; Wood, A.E.; Sarasan, V. Techniques for the collection, transportation, and isolation of orchid endophytes from afar: A case study from Madagascar. Bot. Stud. 2017, 58, 54. [CrossRef] [PubMed]

12. Yagame, T.; Funabiki, E.; Nagasawa, E.; Fukiharu, T.; Iwase, K. Identification and symbiotic ability of Psathyrellaceae fungi isolated from a photosynthetic orchid, Cremastra appendiculata (Orchidaceae). Am. J. Bot. 2013, 100, 1823-1830. [CrossRef] [PubMed]

13. Jacquemyn, H.; Brys, R.; Lievens, B.; Wiegand, T. Spatial variation in below-ground seed germination and divergent mycorrhizal associations correlate with spatial segregation of three co-occurring orchid species. J. Ecol. 2012, 100, 1328-1337. [CrossRef]

14. McCormick, M.K.; Jacquemyn, H. What constrains the distribution of orchid populations? New Phytol. 2014, 202, 392-400. [CrossRef]

15. Mitchell, R.B. Growing hardy orchids from seeds at Kew. Plantsman 1989, 2, 152-169.

16. Clements, M.A.; Muir, H.; Cribb, P.J. A Preliminary Report on the Symbiotic Germination of European Terrestrial Orchids. Kew Bull. 1986, 41, 437. [CrossRef]

17. Zettler, L.W.; Sharma, J.; Rasmussen, F. Mycorrhizal diversity. In Orchid Conservation; Dixon, K.W., Kell, S.P., Barrett, R.L., Cribb, P.J., Eds.; Natural History Publications (Borneo): Kota, India, 2003; pp. 185-203.

18. Batty, A.L.; Dixon, K.; Brundrett, M.C.; Sivasithamparam, K. Long-term storage of mycorrhizal fungi and seed as a tool for the conservation of endangered Western Australian terrestrial orchids. Aust. J. Bot. 2001, 49, 619. [CrossRef]

19. White, T.J.; Bruns, T.; Lee, S.J.; Taylor, J. Amplification and direct sequencing of fungal ribosomal RNA genes for phylogenetics In PCR Protocols: A Guide to Methods and Applications; Innis, M.A., Gelfand, D.H., Sninsky, J.J., White, T.J., Eds.; Academic Press: San Diego, CA, USA, 1990; pp. 315-322.

20. Gardes, M.; Bruns, T.D. ITS primers with enhanced specificity for basidiomycetes-application to the identification of mycorrhizae and rusts. Mol. Ecol. 1993, 2, 113-118. [CrossRef]

21. Taylor, D.L.; McCormick, M.K. Internal transcribed spacer primers and sequences for improved characterization of basidiomycetous orchid mycorrhizas. New Phytol. 2008, 177, 1020-1033. [CrossRef] [PubMed]

22. Yamazaki, J.; Miyoshi, K. In Vitro Asymbiotic Germination of Immature Seed and Formation of Protocorm by Cephalanthera falcata (Orchidaceae). Ann. Bot. 2006, 98, 1197-1206. [CrossRef] [PubMed]

23. McNair, J.N.; Sunkara, A.; Frobish, D.J. How to analyse seed germination data using statistical time-to-event analysis: Nonparametric and semi-parametric methods. Seed Sci. Res. 2012, 22, 77-95. [CrossRef]

24. Rafter, M.; Yokoya, K.; Schofield, E.J.; Zettler, L.W.; Sarasan, V. Non-specific symbiotic germination of Cynorkis purpurea (Thouars) Kraezl., a habitat-specific terrestrial orchid from the Central Highlands of Madagascar. Mycorrhiza 2016, 26, 541-552. [CrossRef]

25. Kendon, J.P.; Yokoya, K.; Zettler, L.W.; Jacob, A.S.; McDiarmid, F.; Bidartondo, M.I.; Sarasan, V. Recovery of mycorrhizal fungi from wild collected protocorms of Madagascan endemic orchid Aerangis ellisii (B.S. Williams) Schltr. and their use in seed germination in vitro. Mycorrhiza 2020, 30, 567-576. [CrossRef]

26. Dycus, A.M.; Knudson, L. The Role of the Velamen of the Aerial Roots of Orchids. Int. J. Plant Sci. 1957, 119, 78-87. [CrossRef]

27. Bayman, P.; Otero, J.T. Microbial Endophytes of Orchid Roots. In Microbial Root Endophytes; Schulz, B.J.E., Boyle, C.J.C., Sieber, T.N., Eds.; Soil Biology; Springer: Berlin/Heidelberg, Germany, 2006; Volume 9. [CrossRef]

28. Bell, J.; Yokoya, K.; Kendon, J.P.; Sarasan, V. Diversity of root-associated culturable fungi of Cephalanthera rubra (Orchidaceae) in relation to soil characteristics. PeerJ 2020, 8, e8695. [CrossRef] [PubMed]

29. McCormick, M.K.; Whigham, D.F.; O'Neill, J. Mycorrhizal diversity in photosynthetic terrestrial orchids. New Phytol. 2004, 163, 425-438. [CrossRef] 
30. McCormick, M.K.; Whigham, D.F.; Sloan, D.; O'Malley, K.; Hodkinson, B. Orchid-Fungus Fidelity: A Marriage Meant to Last? Ecology 2006, 87, 903-911. [CrossRef]

31. Jacquemyn, H.; Honnay, O.; Cammue, B.P.A.; Brys, R.; Lievens, B. Low specificity and nested subset structure characterize mycorrhizal associations in five closely related species of the genus Orchis. Mol. Ecol. 2010, 19, 4086-4095. [CrossRef]

32. Fracchia, S.; Rickert, A.M.A.; Flachsland, E.; Terada, G.; Sede, S.M. Mycorrhizal compatibility and symbiotic reproduction of Gavilea australis, an endangered terrestrial orchid from south Patagonia. Mycorrhiza 2014, 24, 627-634. [CrossRef]

33. Zettler, L.W.; Corey, L.L.; Jacks, A.L.; Gruender, L.T.; Lopez, A.M. Tulasnella irregularis (basidiomycota: Tulasnellaceae) from roots of Encyclia tampensis in south Florida, and confirmation of its mycorrhizal significance through symbiotic seed germination. Lankesteriana 2013, 13, 119-128. [CrossRef]

34. Otero, J.T.; Ackerman, J.D.; Bayman, P. Differences in mycorrhizal preferences between two tropical orchids. Mol. Ecol. 2004, 13, 2393-2404. [CrossRef]

35. Otero, J.T.; Flanagan, N.S.; Herre, E.A.; Ackerman, J.D.; Bayman, P. Widespread mycorrhizal specificity correlates to mycorrhizal function in the neotropical, epiphytic orchid Ionopsis utricularioides (Orchidaceae). Am. J. Bot. 2007, 94, 1944-1950. [CrossRef]

36. Suárez, J.P.; Weiss, M.; Abele, A.; Garnica, S.; Oberwinkler, F.; Kottke, I. Diverse tulasnelloid fungi form mycorrhizas with epiphytic orchids in an Andean cloud forest. Mycol. Res. 2006, 110, 1257-1270. [CrossRef]

37. Suárez, J.P.; Weiß, M.; Abele, A.; Oberwinkler, F.; Kottke, I. Members of Sebacinales subgroup B form mycorrhizae with epiphytic orchids in a neotropical mountain rain forest. Mycol. Prog. 2008, 7, 75-85. [CrossRef]

38. Xing, X.; Ma, X.; Deng, Z.; Chen, J.; Wu, F.; Guo, S. Specificity and preference of mycorrhizal associations in two species of the genus Dendrobium (Orchidaceae). Mycorrhiza 2013, 23, 317-324. [CrossRef] [PubMed]

39. Whitman, M.; Medler, M.; Randriamanindry, J.J.; Rabakonandrianina, E. Conservation of Madagascar's granite outcrop orchids: The influence of fire and moisture. Lankesteriana Int. J. Orchid. 2011, 11, 55-67. [CrossRef]

40. Rasmussen, H.N. Terrestrial Orchids: From Seed to Mycotrophic Plant; Cambridge University Press: Cambridge, UK, 1995.

41. Crawford, N.M. Nitrate: Nutrient and signal for plant growth. Plant Cell 1995, 7, 859.

42. Dechorgnat, J.; Nguyen, C.T.; Armengaud, P.; Jossier, M.; Diatloff, E.; Filleur, S.; Daniel-Vedele, F. From the soil to the seeds: The long journey of nitrate in plants. J. Exp. Bot. 2011, 62, 1349-1359. [CrossRef]

43. Figura, T.; Weiser, M.; Ponert, J. Orchid seed sensitivity to nitrate reflects habitat preferences and soil nitrate content. Plant Biol. 2020, 22, 21-29. [CrossRef] [PubMed]

44. Nurfadilah, S.; Swarts, N.D.; Dixon, K.W.; Lambers, H.; Merritt, D.J. Variation in nutrient-acquisition patterns by mycorrhizal fungi of rare and common orchids explains diversification in a global biodiversity hotspot. Ann. Bot. 2013, 111, 1233-1241. [CrossRef] [PubMed] 